\title{
Criminal liability for insurance fraud in the Romano-German legal system
}

\author{
Amid Gasanov ${ }^{1, *}$ \\ ${ }^{1}$ RUDN University, Miklouho-Maclay str., 6, Moscow, 119670 , Russia
}

\begin{abstract}
The article is devoted to the issue of fighting insurance fraud in the states of Romano-German legal system. The aim of the work is to study the experience of the states of Romano-German legal system in field of fighting insurance fraud. For the analysis of foreign criminal law, the comparative legal method was used. In addition, study was carried out using formal logical, dialectical method of cognition of social and legal phenomena, as well as methods of induction and deduction. Based on the study of legislative separate states, the author notes a number of specific features of development of this legislation. In particular, it is indicated that in relation to the issue of establishing liability for insurance fraud in the criminal law of the European states of the Romano-German legal system, there are three main approaches: liability comes within the framework of general rules on fraud (France); liability is partially established in the framework of special criminal law on liability for insurance fraud, partly such liability arises in accordance with general criminal law in the field of fraud (for example, Germany, Austria); liability for insurance fraud is provided in the framework of special criminal law on liability in the area in question (for example, Holland, Italy) and a number of others.
\end{abstract}

\section{Introduction and methods}

Insurance fraud is currently one of the most common types of fraud. In the Russian Federation, liability for insurance fraud is a relative novelty in criminal law. In this regard, it is relevant to study foreign experience in establishing criminal liability for criminal offense under consideration. Russian criminal law is considered the closest to the RomanoGerman legal system. [1,2]Therefore, the study of criminal laws of these states seems logical from the point of view of possible perception of experience in the area of responsibility for this act. In addition, it should be noted that insurance fraud is an urgent problem for many states belonging to the Romano-German legal system. Thus, it is noted that in the Netherlands, payments to fraudsters account for approximately $5 \%$ of all insurance payments, reaching approximately \$300 million. The European Insurance Committee estimates the losses from fraud in Europe at 8 billion euros, which is $2 \%$ of all insurance premiums in the countries of the European Union, with at least $10 \%$ of all payments received by fraudsters. [3]

The aim of the work is to study the experience of the states of Romano-German legal

"Corresponding author: criminal-law@mail.ru 
system in field of fighting insurance fraud.

As a subject of research, we will consider criminal law of a number of European countries for which the problem of insurance fraud is currently particularly relevant or where special legislation has been proposed in field of criminal liability for insurance fraud. For research, we have selected following criminal laws: Germany, France, Austria, Holland and Italy.

For the analysis of foreign criminal law, the comparative legal method was used. In addition, study was carried out using formal logical, dialectical method of cognition of social and legal phenomena, as well as methods of induction and deduction.

The author has used both literature in Russian, devoted to the problems of fighting insurance fraud and works performed by foreign scientists.

\section{Results}

We begin our study with criminal law of Germany. In Germany, damage from insurance fraud is estimated at $5-8 \%$ of the amount paid. However, there is an opinion that the amount of abuse is actually much larger, and only in transport insurance reaches about 2.5 billion dollars a year. In Germany, as well as in other European countries, most crimes are recorded in the auto insurance sector. The most common method of dishonest clients is fake theft of motor vehicles. According to various opinion polls, about $15 \%$ of Germans do not consider insurance fraud a crime, and about $25 \%$ of Germans deceived the insurers at least once in their lives. However, in most cases, scammers managed to get on average no more than 500 euros [1]. The doctrine of German criminal law also emphasizes the particular relevance of countering fraudulent activities in the insurance industry [1].

These statistics show the high relevance of criminal law measures to fight insurance fraud in the Federal Republic of Germany.

Analyzing the criminal law of Germany in field of liability for insurance fraud, it should be noted a number of aspects:

1. The criminal law of Germany actually provides for two criminal law provisions establishing liability for insurance fraud. The general rule on fraud covers most criminal acts related to insurance fraud. At the same time, a special criminal law provision assumes responsibility for a number of acts directly related to abuse in the insurance industry. For example, a person who causes damage to the insured property in order to receive an insurance premium in the future is liable. The general rule on fraud also specifically states cases of skilled fraud. In particular, liability is provided for those who falsify insured accident or a person sets fire to a thing of significant value for this purpose, or by destroying it completely or partially, or drowns the ship.

2. In German criminal law, a special norm on fraud implies a less severe criminal punishment for a committed act than the general criminal law norm on liability for fraud. Thus, the German lawmaker refers the most socially dangerous cases of insurance fraud (those associated with causing great damage) to the general rule on fraud. The punishment for such an act can reach 10 years in prison. At the same time, liability for abuse in the insurance industry cannot exceed three years in prison.

3. When analyzing the dispositions of criminal law rules on liability for insurance fraud under the Criminal Code of the Federal Republic of Germany, it should be noted that the abuse of fraud, in understanding of German lawmakers, actually involves artificial creation of an insured case for the insured property (for example, destruction, otherwise creating the appearance of loss).

In general, analyzing criminal legislation of Germany in the area of liability for insurance fraud, it should be noted that German lawmakers provided for possible liability for the most socially dangerous cases of insurance fraud within the framework of general 
rule on fraud; for special cases of abuse of insurance associated with damage or intentional loss of property, a less severe punishment.

The authors have also considered the criminal law of France in field of liability for insurance fraud. In France, losses caused by dishonest customers of insurance companies are estimated at about $\$ 3$ billion. According to some statistics, only disclosed cases of fraud account for a total of $10 \%$ of the insurance indemnity paid. Despite this, there is a general belief that France is leading in Europe in the effectiveness of organizing fight against insurance crime. [1] In 2015, the Anti-Fraud Agency (Alfa) identified 46,455 fraud cases, which allowed insurance companies to save 265 million euros. Thus, we can talk about high relevance of the problem of fighting insurance fraud for the French legislator. The anti-insurance fraud counteraction is also highlighted in the doctrine of French criminal law[4].

However, in France there is no legal definition of insurance fraud. The Alfa Insurance Fraud Agency, however, believes - with the approval of practitioners - that insurance fraud occurs whenever a deliberate act occurs in order to obtain illegal profit under an insurance contract. The fraudster therefore allows fraud in relation to the insurer acts intentionally[3].

French criminal law does not have a special rule on liability for insurance fraud. Such responsibility is established by the general norm of the Criminal Code.

Analyzing French criminal law in the area of liability for insurance fraud, a number of aspects should be noted:

1. The French legislator, despite the high urgency of the problem of fighting insurance fraud, has not taken the path of differentiating criminal liability for the crime in question. Responsibility for insurance fraud is provided under the general rule on liability for this crime.

2. It should be noted that French criminal law provides for less severe penalties for this type of fraud compared to German criminal law. The maximum term of imprisonment may not exceed 5 years.

3. From the point of view of describing the signs of the objective side of the considered type of fraud, it should be noted that in the French Criminal Code liability is established for various cases of fraud or abuse, in particular, abuse of product quality.

In general, analyzing French criminal law in field of liability for insurance fraud, it should be noted that its feature is the lack of differentiation of liability for insurance fraud. As a result, insurance fraud is not considered by the French legislator either as a privileged offense or as an act with an increased degree of public danger.

Continuing our research, we have considered Austrian criminal law in field of insurance fraud. The criminal legislation of this country is traditionally closely related to the criminal law of Germany.

It is of interest, first of all, in the context that Austrian Criminal Code [5] provides for a special rule on liability for insurance fraud. Experts note a relatively large number of cases of insurance fraud in Austria [6].

In general, considering the features of Austrian criminal law in the area of liability for insurance fraud, it should be noted:

1. Austrian criminal law contains a special provision providing for liability for various fraudulent abuses related to insurance activities. It should be noted that, unlike German criminal law, this norm covers a significant list of acts.

2. From the point of view of the objective side of the crime in question, Austrian criminal law provides for liability:

a) creating appearance of an insured case by causing harm to the insured property;

b) creating appearance of an insured case by causing harm to the life and health of an insured person. 
3. Austrian criminal law provides for relatively lax penalties for insurance fraud. In particular, the most severe punishment is imprisonment for up to 6 months. Such penalties are less severe in comparison with the criminal laws of the Federal Republic of Germany and France that we have previously studied. Moreover, for ordinary fraud without extenuating and aggravating circumstances, the Austrian Criminal Code provides for a similar penalty. For severe cases of fraud the criminal law provides a more severe punishment, which can reach 10 years in prison.

4. Among the peculiarities of Austrian criminal law in field of liability for insurance fraud, it should be noted that there is a rule on the voluntary refusal to commit it before the receipt of the insurance premium.

In general, analyzing Austrian criminal law in field of liability for insurance fraud, it should be noted that in the framework of the Criminal Code of Austria, differentiation of criminal liability and abuse in the insurance process were singled out as an independent crime. At the same time, the Austrian lawmaker perceives this act as a crime with an equal degree of public danger in comparison with other cases of fraud committed without aggravating and mitigating circumstances. This is evidenced by the establishment of similar penalties for the crime in question.

There are also special rules on liability for insurance fraud in the Netherlands. For this country, the problem of fighting insurance fraud is currently very relevant. Thus, it is noted that in the Netherlands, payments to fraudsters account for approximately $5 \%$ of all insurance payments, reaching approximately $\$ 300$ million [1]. Dutch scientists also point out significant insurance issues related to increasingly frequent cases of insurance fraud [7].

Analyzing the dispositions of the criminal law in the area of liability for insurance fraud in the Netherlands, it should be noted that:

1. Dutch criminal law provides for liability in fact for two groups of acts related to insurance fraud:

a) directly fraud regarding the insured case (when the guilty person creates appearance of the insured case by concealing the property or intentionally damaging it for the purpose of obtaining the insurance premium later)

b) deception or misrepresentation in the process of concluding an insurance contract. In this case, in particular, we are talking about concealment of any factors, the knowledge of which would affect the decision of the insurer to conclude an appropriate insurance contract (for example, information about an incurable disease).

In this context, it should be noted that the Dutch legislator provides a wider list of acts related to insurance fraud compared to the criminal laws that we previously examined in Germany, France and Austria.

2. In Dutch criminal law, the severity of punishment for insurance fraud generally corresponds to the trends of other European states of the Romano-German legal system, in particular, France and Austria. In this case, deception regarding an insured case is considered by the Austrian legislator as an act with a greater degree of public danger compared with a deception regarding the conditions for concluding insurance contracts. For the first act, the most severe punishment is 4 years in prison; for the second act of not more than a year in prison.

In general, analyzing criminal legislation in the area of liability for insurance fraud, it should be noted that it is distinguished by the differentiation of liability for ordinary fraud and insurance fraud. Moreover, unlike other criminal laws of the states of the RomanoGermanic legal system examined, the Dutch Criminal Code provides for liability for two types of acts: a) fraud regarding an insured case; b) deception or misrepresentation in the process of concluding an insurance contract.

Next we have considered the Italian criminal law in the area of liability for insurance fraud. The doctrine of law contains a large number of cases of insurance fraud in Italy. 
Especially in this area, fraud in field of motor insurance should be noted [8]. An Italian lawmaker has proposed an interesting solution in the area of liability for insurance fraud according to Art. 642 of the Criminal Code of Italy [9] (fraudulent damage to insured assets and fraudulent personal injury).

Analyzing the disposition of criminal law norm of the Italian legislation on liability for insurance fraud, attention should be paid to a number of aspects:

1. Italian criminal law establishes liability in fact for three types of acts related to insurance fraud:

a) destruction or damage to the insured property;

b) intentionally causing harm to the life and health of an insured person; It should be noted that Italian lawmaker separately stipulates that a person is liable not only if he created an insured case, but also if he worsened his condition, which led to additional insurance payments.

c) falsification of documents regarding the insured case.

In this context, it should be noted a wide range of acts, responsibility for which is established under Italian criminal law. Such a wide range of special acts related to insurance fraud among European states of the Romano-German legal system is contained only in the Dutch criminal law.

2. The Criminal Code of Italy separately states the question that liability arises even if the act was committed outside Italy, but Italian insurer was harmed.

3. With regard to the issues of punishment for insurance fraud, Italian legislator also follows the main trends in legislation of European states of the Romano-German legal system. The most severe punishment is imprisonment of up to 5 years.

In general, analyzing Italian criminal law in field of liability for insurance fraud, it should be noted a wide range of acts in this area for which liability is provided under Italian Criminal Code. In particular, liability has been established for the following acts committed to create appearance of an insured case: destruction or damage to the insured property; intentional harm to the life and health of an insured person; falsification of documents regarding the insured case.

Table 1 presents the characteristics of criminal law of European states of the RomanGerman legal system in the area of liability for insurance fraud.

\section{Discussion}

Continuing our research, we have examined in more detail the features of criminal law of European states of the Romano-German legal system in field of liability for insurance fraud:

1. In relation to the issue of establishing liability for insurance fraud in criminal law of European states of the Romano-German legal system, there are three main approaches:

a) liability arises under the general rules on fraud (France). In this case, there is no special criminal law on liability for insurance fraud in the criminal law. Moreover, all acts committed in this area are covered by the general criminal law on fraud or other crimes against property;

b) liability is partially established in the framework of special criminal law on liability for insurance fraud, partly such liability arises in accordance with the general criminal law in field of fraud (for example, Germany, Austria). Thus, there is a differentiation of criminal liability and a number of acts related to insurance fraud are identified as independent offenses; 
Table 1. Characteristic of criminal low of European states in the area of liability for insurance fraud

\begin{tabular}{|c|c|c|c|c|}
\hline № & Country & Regulation source & Criminal offenses & Punishment \\
\hline 1. & Germany & $\begin{array}{l}\text { the liability is } \\
\text { partially established } \\
\text { in the framework of } \\
\text { special criminal law } \\
\text { on liability for } \\
\text { insurance fraud, } \\
\text { partly such liability } \\
\text { arises in accordance } \\
\text { with the general } \\
\text { criminal law in the } \\
\text { field of fraud }\end{array}$ & $\begin{array}{l}\text { a) destruction or damage } \\
\text { to the insured property; } \\
\text { b) intentionally causing } \\
\text { harm to the life and health } \\
\text { of the insured person; } \\
\text { c) falsification of } \\
\text { documents regarding the } \\
\text { insured case }\end{array}$ & $\begin{array}{l}\text { the most socially } \\
\text { dangerous } \\
\text { insurance fraud } \\
\text { cases are related } \\
\text { to the general } \\
\text { fraud rule. The } \\
\text { punishment for } \\
\text { such an act can } \\
\text { reach } 10 \text { years in } \\
\text { prison. At the } \\
\text { same time, } \\
\text { liability for abuse } \\
\text { in the insurance } \\
\text { industry cannot } \\
\text { exceed three years } \\
\text { in prison. }\end{array}$ \\
\hline 2. & France & $\begin{array}{l}\text { liability arises under } \\
\text { the general rules on } \\
\text { fraud }\end{array}$ & $\begin{array}{l}\text { liability is established for } \\
\text { various cases of fraud or } \\
\text { abuse. In particular, abuse } \\
\text { of product quality. }\end{array}$ & $\begin{array}{l}\text { The maximum } \\
\text { term of } \\
\text { imprisonment } \\
\text { may not exceed } 5 \\
\text { years }\end{array}$ \\
\hline 3. & Austria & $\begin{array}{l}\text { the liability is } \\
\text { partially established } \\
\text { in the framework of } \\
\text { special criminal law } \\
\text { on liability for } \\
\text { insurance fraud, } \\
\text { partly such liability } \\
\text { arises in accordance } \\
\text { with the general } \\
\text { criminal law in the } \\
\text { field of fraud }\end{array}$ & $\begin{array}{l}\text { a) creating the } \\
\text { appearance of an insured } \\
\text { event by causing harm to } \\
\text { the insured property; } \\
\text { b) creating the appearance } \\
\text { of the insured event by } \\
\text { causing harm to the life } \\
\text { and health of the insured } \\
\text { person. }\end{array}$ & $\begin{array}{l}\text { The most severe } \\
\text { punishment is } \\
\text { imprisonment for } \\
\text { up to } 6 \text { months. }\end{array}$ \\
\hline 4. & Holland & $\begin{array}{l}\text { liability for } \\
\text { insurance fraud is } \\
\text { provided for in the } \\
\text { framework of } \\
\text { special criminal law } \\
\text { rules on liability in } \\
\text { this area }\end{array}$ & $\begin{array}{l}\text { a) directly fraud regarding } \\
\text { the insured event; } \\
\text { b) deception or } \\
\text { misrepresentation in the } \\
\text { process of concluding an } \\
\text { insurance contract. }\end{array}$ & $\begin{array}{l}\text { the severity of } \\
\text { punishment for } \\
\text { insurance fraud } \\
\text { generally } \\
\text { corresponds to the } \\
\text { trends of other } \\
\text { European states of } \\
\text { the Romano- } \\
\text { German legal } \\
\text { system, in } \\
\text { particular, France } \\
\text { and Austria }\end{array}$ \\
\hline 5. & Italy & $\begin{array}{l}\text { liability for } \\
\text { insurance fraud is } \\
\text { provided for in the } \\
\text { framework of } \\
\text { special criminal law } \\
\text { rules on liability in } \\
\text { this area }\end{array}$ & $\begin{array}{l}\text { a) destruction or damage } \\
\text { to the insured property; } \\
\text { b) intentionally causing } \\
\text { harm to the life and health } \\
\text { of the insured person; } \\
\text { c) falsification of } \\
\text { documents regarding the } \\
\text { insured case. }\end{array}$ & $\begin{array}{l}\text { The most severe } \\
\text { punishment is } \\
\text { imprisonment of } \\
\text { up to } 5 \text { years. }\end{array}$ \\
\hline
\end{tabular}


c) liability for insurance fraud is provided in the framework of special criminal law on liability in the area in question (for example, the Netherlands, Italy). In this case, there is a differentiation of responsibility. Insurance fraud is considered as an independent type of criminal act. Accordingly, liability for such acts is provided for in the framework of one or more special criminal law norms.

2. Regarding the description of the signs of the objective side of insurance fraud, it should be noted that criminal law of the states of the Romano-German legal system as a whole establishes liability for three types of acts committed in order to create the appearance of an insured case: a) destruction or damage of the insured property; b) intentionally causing harm to the life and health of an insured person; c) falsification of documents regarding the insured case. Moreover, only in two criminal laws examined by us are liability for all three of these acts provided for in the framework of special criminal law norms (the Netherlands and Italy). In remaining criminal laws, either some (Germany, Austria) or all the acts in question (France) are covered by general criminal law rules establishing liability for fraud or other crimes against property.

3. With regard to the question of perception of the degree of public danger of insurance fraud in criminal law of the states of the Romano-German legal system as a whole, there is a single trend according to which this act, despite the differentiation of criminal liability for it, is perceived as a crime with an approximately equal degree of public danger with respect to other cases of fraud and property crimes. This factor, first of all, is indicated by the severity of the punishment provided for the investigated type of fraud in the sanctions of the articles of the Criminal Code. In the overwhelming majority of criminal laws examined by us (Italy, Austria, the Netherlands), the punishment for the crime in question is either identical with respect to other types of fraud, or very similar in severity.

\section{Conclusion}

In general, summing up the study of issues of criminal liability for insurance fraud $[15,16$, $17,18,22,24,30]$ in criminal law of the states of the Romano-German legal system, it should be noted:

1. In relation to the issue of establishing liability for insurance fraud in criminal law of European states of the Romano-German legal system, there are three main approaches:

a) liability arises under the general rules on fraud (France);

b) liability is partially established in the framework of special criminal law on liability for insurance fraud, partly such liability arises in accordance with the general criminal law in the field of fraud (for example, Germany, Austria);

c) liability for insurance fraud is provided in the framework of special criminal law on liability in the area in question (for example, the Netherlands, Italy).

2. Among the features of criminal law of the states of the Romano-German legal system in field of liability for insurance fraud should be noted:

a) criminal law of the states of the Romano-German legal system establishes liability for three types of acts committed in order to create the appearance of an insured case: a) destruction or damage to the insured property; b) intentionally causing harm to the life and health of an insured person; c) falsification of documents regarding the insured case. At the same time, responsibility for these acts can be established both within the framework of special rules (the Netherlands and Italy), or partially or fully within the framework of general rules (Germany, Austria, France).

b) on the issue of the degree of public danger of insurance fraud in criminal law of the states of the Romano-German legal system as a whole, there is a single trend according to which this act is perceived as a crime with an equal degree of public danger in relation to other cases of fraud and property crimes. 


\section{References}

1. S.E. Goldberg, M.S. Fragala, J.G. Wohlgemuth, Population Health Management 22(6), 547-554 (2019). DOI: 10.1089/pop.2018.0184

2. E.P. Hoffer, American Journal of Medicine 132(12), 1381-1385 (2019). DOI: 10.1016/j.amjmed.2019.10.003

3. V.G. Avakyan, Baikalresearchjournal, 2, 12-14 (2011).

4. S. Kastner, Versicherungsbetrug in der Sphäre der Vermittler-Kunden-Beziehung. (Hamburg, 2013)

5. I.N. Romanova, I.A. Mikhailova, Lecture Notes in Networks and Systems 87, 387-395 (2020). DOI: 10.1007/978-3-030-29586-8_45

6. S. Park, B.K. Goodwin, X. Zheng, R.M. Rejesus, Geneva Papers on Risk and Insurance: Issues and Practice, 45(1), 157-183 (2020). DOI: 10.1057/s41288-019-00143-9

7. H. Andre, A.K. Dewi, F. Pangemanan, G. Wang, International Journal of Emerging $\begin{array}{lllll}\text { Trends in } & \text { Engineering } & \text { (2019). }\end{array}$ DOI: $10.30534 /$ ijeter/2019/117122019

8. M. Franze, StrafrechtlicheInstrumentarienzurEindämmung von Versicherungsbetrug (Koln, 2012)

9. B. Sameh, La Fraude À L'Assurance Et L'Audit. (Paris, 2010)

10. Criminal Code of Austria (official text). Available at: https://www.jusline.at/gesetz/stgb

11. V. Koneke, H. Muller-Peters, D. Fetchehauer, Versicherungsbetrug verstehen und verhindern (Koln, 2015)

12. B. De Vos Horizontalewerking van grondrechten: eenkritiek (Antwerpen, 2010)

13. C. Dabrassi, P. Prandi, La responsabilitàcivileautomobilistica. Strategie, innovazione e normative neimodelli di offerta, pp. 472-475 (Milan, 2013)

14. Criminal Code of Italy (official text). Available at: https://www.brocardi.it/codicepenale/titolo-xiii/libro-secondo/capo-ii/

15. V.A. Kiri, ,A.C. Ojule, The Nigerian postgraduate medical journal 27(1), 1-7 (2020). DOI: $10.4103 /$ npmj.npmj_141_19

16. S. Belciug, F.Gorunescu, Intelligent Systems Reference Library 157, 71-102 (2020). DOI: $10.1007 / 978-3-030-14354-1 \_3$

17. K.A. Shakil, F.J. Zareen, M. Alam, S. Jabin, Journal of King Saud University -

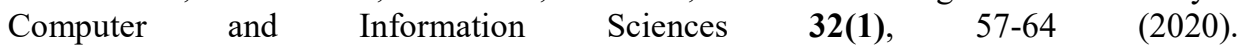
DOI: $10.1016 /$ j.jksuci.2017.07.001

18. P.J. García, The Lancet 394(10214), 2119-2124 (2019). DOI: 10.1016/S01406736(19)32527-9

19. B. Sameh, La Fraude À L'Assurance Et L'Audit (Paris, 2010).

20. R. Kolobov, U. Filatova, V. Borshcheniuk, N. Semerianova, D. Bayanov, E3S Web of Conferences 2019, 110, 02095 (2019). DOI: 10.1051/e3sconf/201911002095

21. V.A. Lez'Er, N.A. Semeryanova, A.V. Kopytova, MATEC Web of Conferences, 239, 04027 (2018). DOI: 10.1051/matecconf/201823904027

22. N. Semeryanova, O. Fedorenko, A. Kopytova, MATEC Web of Conferences, 239, 04013 (2018). DOI: 10.1051/matecconf/201823904013

23. E. Vozniak, A. Burgundosova, A. Kopytova, MATEC Web of Conferences, 239, 01016 (2018). DOI: $10.1051 /$ matecconf $/ 201823901016$ 
24. M. Galeotti, G. Rabitti, E. Vannucci, European Journal of Operational Research (2020) DOI: 10.1016/j.ejor.2020.01.017

25. V. Lez'Er, N. Semerianova, A. Kopytova, Y. Truntsevsky, E3S Web of Conferences 2019, 110, 02093 (2019) DOI: 10.1051/e3sconf/201911002093

26. D. Izvin, V. Lez'Er, A. Kopytova, MATEC Web of Conferences, 170, 01065 (2018). DOI: $10.1051 /$ matecconf $/ 201817001065$

27. O.V. Kozminykh, Entrepreneurship and Sustainability Issues 7(2), 1404-1412 (2019). DOI: $10.9770 /$ jesi.2019.7.2(42)

28. A. Kopytova, MATEC Web of Conferences 106, 08056 (2017). DOI: $10.1051 /$ matecconf/201710608056

29. A.V. Kopytova, N.S. Zotkina, I.G. Reshetnikova, MATEC Web of Conferences 239, 04012 (2018). DOI: 10.1051/matecconf/201823904012

30. J.M. Johnson, T.M. Khoshgoftaar, Journal of Big Data 6(1), 63 (2019). DOI: $10.1186 / \mathrm{s} 40537-019-0225-0$ 